\title{
The Effect of Implementation Authentic Assessment Development Result based on ICT Toward Student's Learning Outcome in Learning Process by 2013 Curriculum
}

\author{
I Nyoman Jampel \\ Primary Teacher Education Department, Ganesha University of Education, Bali, Indonesia \\ Email: nyoman_jampel@yahoo.co.id \\ I Wayan Widiana \\ Primary Teacher Education Department, Ganesha University of Education, Bali, Indonesia \\ Email: wayan_widiana@yahoo.co.id \\ Dewa Gede Hendra Divayana \\ Information Technology Education Department, Ganesha University of Education, Bali, Indonesia \\ Email: divayana182@gmail.com
}

\begin{abstract}
This research purpose was to know the differences of student's learning outcome between the students which is learn through the implementation of authentic assessment development result based on ICT with the students which is learn through conventional assessment at grade V cluster V Sukasada sub district Buleleng regency in the academic year 2013/2014. This research was quasi-experiment research. The population of this research is all the grade $\mathrm{V}$ students at cluster $\mathrm{V}$ Sukasada sub district in amount of five classes. The sample of this research is the grade V students at SD N 2 Pacung which is consist of 23 students and the grade $\mathrm{V}$ students at SD N 1 Julah which is consist of 23 students, the sampling technique used was random sampling. The data collected by test instrument that is 35 questions of objective test and then analysis by descriptive statistic and inferential statistic (t-test). Based on the data analysis, provable that $\mathrm{t}_{\text {count }}=3.67$ and $\mathrm{t}_{\text {table }}$ (at significant standard $5 \%)=2.02$. This is means that $t_{\text {count }}>t_{\text {table }}$, so it can be interpreted that there is significant differences of learning outcome between the students which is learn through the implementation of authentic assessment development result based on ICT in learning process by 2013 curriculum with the students which is learn through conventional assessment. By arithmetic average, it can be known that the average score of the experiment group student's is 26.35 and the average score of the control group student's is 23.30. It's mean that the average score of experiment group $>$ the average score of control group, so it can be conclude that the implementation of authentic assessment development result based on ICT in learning process by 2013 curriculum had an positive effect through the students grave $\mathrm{V}$ learning outcome at cluster V Sukasada sub district, Buleleng regency.
\end{abstract}

Index Terms-Authentic, Assessment, ICT.

\section{INTRODUCTION}

According to Permendiknas No. 2 Tahun 2010, The Vision of Kemdiknas 2025 is to make Indonesian become intelligent and competitive. Indonesian intelligent and competitive is human being which is has comprehensive intelligent that is spiritual intelligent, emotional intelligent, social intelligent, intellectual intelligent, and kinesthetic intelligent. That vision can be establish by the implementation of 2013 curriculum. The teacher asks to internalization that curriculum appropriate with potential, the development of the students, the need of the students, the surrounding school, and the science and technologies development. The learning and teaching process in 2013 curriculum disposed to (1) student centered, (2) competent based, (3) authentic assessment and (4) character values based. But the reality showed that some of the teachers can't do it professionally because they have lack of competence. The result of competence test that done by LPMP Bali showed that the average of mastery six test subjects that include (1) learning management, (2) education concept, (3) tematik, (4) social science, (5) science, and (6) mathematic is below $50 \%$ (LPMP Bali, 2012). Beside that the urgency of this research is the beginning of 2013 curriculum to be use in elementary school. Some of changing that happened in 2013 curriculum are the change is graduate competence standard, process standard, substance standard and evaluation standard. And its curriculum focusing in some aspects of learning, that are: the reinforcement of affection based curriculum in learning process; the reinforcement of knowledge; the reinforcement of student 
active, means that from student given information become student knows the information from many learning sources and the reinforcement of process and outcome. The 2013 curriculum make serious effort in reinforcement of learning effectively and learning process which is supporting creativity. The evaluation process also supporting creativities in developing high thinking ability from early period. It's strengthen by the focus of 2013 curriculum that are: minimize/integrated the subject of learning; minimize the learning material; adding learning period; the reinforcement of based competence curriculum implementation in learning; the reinforcement in learning, skills and attitude in learning; the reinforcement of student active, means that from student given information become student knows the information from many learning sources; the reinforcement of process and outcome; perceptive in social alteration in locally, national and global.

Good class is not only supported by innovative learning model but also need better assessment ability through student's competence attainment. There are many alternative assessments that can be used in inferential statistic subject such as performance assessment. Performance assessment is a kind of assessment that done towards student's performance, attitude, and interaction inside the class. The interaction can be interaction from student to student, student with their lecture or interaction student with their own learning material. So that performance assessment is an assessment that more emphasize to the process without give of the result or learning outcome.

Based on that problems teacher should develop assessement model which can improve learning: from teacher centered to student centered, from content-based learning to competency-based learning, from paper and pencil test assessment to authentic assessment and form material-based education to character values-based education so it can create student experience to develop and shaping exelent character.

Authentic asessement has some advantages if developed in ICT based learning, such are: (1) competence based that is assessment that can observe someone competence. The basic of authentic assessement is kinerja assessment, that is a performance which is showed because the process of comprehensive learning. Competence is student's indivitual attribute, because of that competence based assessement is done (2) individually. Everyone competence is can't be the same , it's personal. Because of that, formal assessment that used to observed student's ability can't accurately measure individual competence; (3) it's student centered because it's planned, done and judged by student itself; give maximum expression to individual excess and also individual lack (in order to improve it). Authentic assessment is unstuctured and open-ended, in the meaning of authentic task completion velocity is not have quality of uniformed and clasical, and also the individual work in a group is not always the same. To make sure that it's access the real individual (student's) competence, so the assessment must be done (4) autheticaly (real in daily life) and appropriate with the learning process, until authentic assessemnt have it's (5) integrating during the learning process. Authentic assessment is (6) on-going or continuous, therefore asessement must be done directly during the process and learning outcome. So, it can be seen that authentic asessement is student centered, learning process integrating, authentic, continuous and individually.

Specal quality of comprehensive authentic assessement also can develop student's metacognition elements, such as risk-taking, creative, developed high level of thinking and divergen, responsibility toward their taks and work and ownership.

Besides that, the use of technology in learning process is give a new face of learning and become different from traditional way of learning, it's showed by the way of student and teacher interaction inside or outside the class so technology can be the media to distribute massage, include post system, radio broadcast, television, telephone, satellite and computer network. So, it can be conclude that the relevant technology for learning is assimilate with the learning itself. According to Ase Suherlan (2000: 48) showed that the essence of learning based on technology is transactional communication which is two ways between teacher and student, or between student itself and learning environment in the efforts of learning objective attainment. From the explanation above we can see that the meaning of learning must be contains communication and information elements.

Communication and information technology efficiency in school is one of the efforts to increase learning quality in Indonesia. Many research in Indonesia or overseas showed that the used of learning source that created in the ICT based learning media can increase the quality of education. In the line with that, now days in e-learning generation, people's awareness about learning and teaching process by using ICT is increasing. Based on that reason, now is the best time to stimulate society to start using technology as efforts to developing human resources. However in Indonesia, the used of ICT based learning media in form of e-learning is still in low number. So it's needed to stimulate people's awareness to give more attention in increasing the qualities and quantities of ICT based learning media to be used in Indonesia.

To achieve the demand of KTSP implementation, it's so important to develop some assessments model which is can increase the competence in 2013 curriculum implementation. That assessment models are: project assessment and activities assessment. The development of authentic assessment can be done by Lesson Study approach. "Lesson study is a model of educator development by learning investigate in collaborative and incessantly based on colleague principals and mutual learning to develop learning community" (Rusman, 2010: 384). In implementing lesson study there are some steps that should be done, that are: Plan, Do, and See in continuous improvement. Plan step head for design learning activities that can help student to in enjoyable 
learning, so the purpose of study can be accomplish by active and creative learning activities. Planning step cannot be done individually, it should be done together. Some teachers are collaborated to improving the ideas. Planning is starting by problems analyses that face during learning activities. Then, teachers try to find solutions of those problems and put in the lesson plan, teaching materials that include learning media, student work sheet and evaluation method. They will share their experiences so they can learn each other's so every meeting in lesson study called mutual learning.

\section{METHOD}

This research was quasi-experiment research. The first step in this research is developing assessment by ADDIE model. The result development then test in limited samples. The development done specifically in Science (IPA) material. Operationally the development of authentic assessment in 2013 curriculum concentrate to project and activities assessment in science material. The implementation is done by scientific learning. All steps of scientific learning are observe, ask, try/test, think, and communicate.

This research take place in elementary school (SD) in cluster V Sukasada sub district, Buleleng regency in second semester academic year 2013/2014. The population is all fifth grade students of elementary school in cluster V. The total of SD is five schools with total amount of student are 126 students.

The technical sampling that used in this research is random sampling technique. This technique is done by mix all the subjects in population so all subjects has the save priority to be chosen as sample (Agung, 2010). The sample that randomly in this research is classes because its impossible to changing the class. The class which is randomly is in the same grade. That class is the fifth grade class from all elementary school in cluster $\mathrm{V}$ Sukasada sub district Buleleng regency.

From five school in cluster V Sukasada sub district, its lottery to choose two classes to become sample of the research. Based on the result of random sampling, obtained that the student in the fifth grade at SD $\mathrm{N} 2$ Pacung in amount of 23 students and the fifth grade student in SD N 1 Julah in amount of 23 students as sample of the research. And its already chosen that the fifth grade student at SD N 2 Pacung as experiment class and the fifth grade student at SD N 1 Julah as control class. The experiment class given the development of authentic assessment in learning by 2013 curriculum and the control class given conventional model of learning.

The data collected by test method. According to Arikunto (2002:53) " test is a form or procedure which is use to know or to measure something in condition, with way and rules that already set". The test method that used in this research is objective test, consist of 35 question in multiple choices.

The data analysis used in this research is descriptive statistical analysis and inferential statistical analysis. Descriptive statistical analysis is used to count the average point, modus, median, deviation standard, Varian, maximum score and minimum score. Although inferential statistical analysis is used to analysis the hypothesis by $\mathrm{t}$ test (separated variants). Before testing the hypothesis, that are some requirements that should be fulfil and need to be proven. Those requirements are: $\quad$ (1) the data that analysis should in normal distribution, (2) knowing that the data analysis in homogametic or nonhomogametic. Those requirements should be proven first, so normality-test and homogeneity-test is done as requirement-test.

\section{RESULTS}

The validation of authentic assessment was done before experiment. The result of data analysis showed that the percentage of final value is $79.41 \%$ and it's means that authentic assessment based on ICT is valid. Whereas the percentage for every items are $75 \%$ for the lowest and $100 \%$ for the highest in the valid enough and valid, so all the material of authentic assessment based on ICT is valid. Based on the suggestion and comment that given by the judges it's needed some correction to the learning media. The correction that has been done is replacing learning material indicator in material menu and adding rubric in assessment menu. From the data analysis that done by the expert of assessment and measuring it's showed that the percentage of final value is $83.33 \%$, so the authentic assessment based on ICT is in valid category. Whereas the percentage for every items are $75 \%$ for the lowest and $100 \%$ for the highest in the valid enough and valid, so all the material of authentic assessment basen on ICT is valid. Based on suggestions and comment that given by the judges it's needed some correction to the learning media. The correction that has been done is improving rubrict and fixing operational words that inappropriate with learning.

The data description about learning outcome from experimental group and control group that analysis by descriptive statistical showed in table 1 .

Table 1. The Data Description About Learning Outcome From Experimental Group and Control Group

\begin{tabular}{ccc}
\hline Statistical & Experimental Group & $\begin{array}{c}\text { Control } \\
\text { Group }\end{array}$ \\
\hline Highest Score & 31 & 29 \\
Lowest Score & 21 & 18 \\
Spend & 10 & 11 \\
Mean & 26.35 & 23.30 \\
Median & 26.67 & 22.78 \\
Modus & 27.17 & 22.30 \\
Varian & 7.69 & 8.22 \\
Deviation Standard & 2.77 & 2.87 \\
\hline
\end{tabular}

Some requirement-test should be done before the hypothesis-test, its to do to the data of learning outcome which is include normality-test toward post-test score of experimental group and control group, homogeneity-test of Varian from those two groups. Normality-test is done to prove that those two samples is in normal distribution.

Based on the result of normality-test showed that $\mathrm{x}^{2}$ count the result of experimental group post-test is 0.944 and 
$\mathrm{x}_{\text {table }}^{2}$ with significant standard $5 \%$ and $\mathrm{db}=3$ is 7.815 . it's means that; $x_{\text {count }}^{2}$ the result of experimental group post-test is lower than $\mathrm{x}_{\text {table }}^{2}\left(\mathrm{x}_{\text {count }}^{2}<\mathrm{x}_{\text {table }}^{2}\right)$ with the result that the experimental group post-test data is normally distribution. Whereas, $\mathrm{x}^{2}$ count the result of control group post-test is 1.475 and $\mathrm{x}_{\text {table }}^{2}$ with significant standard $5 \%$ and $\mathrm{db}=3$ is 7.815 . it's means that, $\mathrm{x}_{\text {count }}^{2}$ the result of control group post-test is lower than $\mathrm{x}^{2}$ table $\left(\mathrm{x}_{\text {count }}^{2}<\mathrm{x}_{\text {table }}^{2}\right)$ with the result that the control group posttest data is normally distribution.

After knowing the result of normality-test, then continue to homogeneity-test by F-test formula. From Ftest calculation showed that $F_{\text {hit }}$ post-test result of experimental and control group is 1.069 . Whereas $F_{\text {table }}$ with $\mathrm{db}_{\text {numerator }}=22, \mathrm{db}_{\text {denominator }}=22$, and significance standard 5\% is 2.028 . It's means that Varians data of the post-test result of experimental and control group is homogeny.

The test of research hypothesis is showed that there significant differences of learning outcome from the students which is learned through authentic assessment development learning process by 2013 curriculum as compared to the student which is learned through conventional assessment in the fifth grade second semester elementary school cluster V Sukasada subdistrict Buleleng regency academic year 2013/2014.

This hypothesis-test is used independent t-test "uncorrelation sample". Refer to the explanation above showed that the data of student's learning outcome in experimental group and control group is normal distribution and the Varian's of experimental group and control group is homogeny. Besides that the amount of student in every class is the same, although in experimental group or control group, so this t-test uncorrelation sample is used t-test formula separated varians. The result of t-test is showed in Table 2 .

Table 2. Result of Hypothesis-Test

\begin{tabular}{ccccccc}
\hline $\begin{array}{c}\text { Sample } \\
\text { Group }\end{array}$ & $\mathrm{N}$ & $\bar{X}$ & $\mathrm{db}$ & $\mathrm{T}_{\text {count }}$ & $\mathrm{t}_{\text {table }}$ & Conclusion \\
\hline Experiment & 23 & 26.35 & \multirow{2}{*}{44} & 3.67 & 2.02 & $\mathrm{H}_{0}$ rejected \\
\hline Control & 23 & 23.30 & & & & \\
\hline
\end{tabular}

Based on t-test calculation, providable $\mathrm{t}_{\text {count }}=3.67$. whereas $t_{\text {table }}$ with $\mathrm{db}=44$ and significant standard $5 \%$ is 2.02. It's means that $t_{\text {count }}$ is higher than $t_{\text {table }}\left(t_{\text {count }}>t_{\text {table }}\right)$ so $\mathrm{H}_{0}$ is rejected $\mathrm{H}_{1}$ is accepted. And then it can be interpreted that there is significant differences of learning outcome from the students which is learned through authentic assessment development learning process by 2013 curriculum as compared to the student which is learned through conventional assessment in the fifth grade second semester elementary school cluster V Sukasada sub-district Buleleng regency academic year $2013 / 2014$.

\section{DISCUSSION}

This research explain learning outcome from the students which is learned through authentic assessment development learning process by 2013 curriculum as compared to the student which is learned through conventional assessment.

The result of this research showed that learning outcome from the students which is learned through authentic assessment development learning process by 2013 curriculum is different with the student which is learned through conventional assessment. In descriptively the group which is learned through authentic assessment development in learning process by 2013 curriculum has average learning outcome score 26.35 , whereas the group which is learned through conventional assessment has average learning outcome score 23.30. it's showed that learning outcome from the students which is learned through authentic assessment development learning process by 2013 curriculum is higher than learning outcome from the student which is learned through conventional assessment.

The result of t-test toward research hypothesis showed that there is significant differences of learning outcome from the students which is learned through authentic assessment development learning process by 2013 curriculum as compared to the student which is learned through conventional assessment. It can be seen in the result of analysis that already done, the effect of learning model toward student learning outcome have statistic value $\mathrm{t}=3.67$ and $\mathrm{t}_{\mathrm{tab}}(\mathrm{db}=$ and significant standard $5 \%)=$ 2.02. Statistically the result of this research showed that authentic assessment development in learning process by 2013 curriculum and conventional assessment be different significantly in student learning outcome attainment at significant standard 5\%.

This result of research is proven the hypothesis, that is different learning outcome from the students which is learned through authentic assessment development in learning process by 2013 curriculum than the student which is learned through conventional assessment.

Theoretically authentic assessment development in learning process by 2013 curriculum had the edge on conventional assessment. The development of authentic assessment in learning process by 2013 curriculum can be perceivable as student centered learning with teacher as moderator and facilitator whereas student construct their knowledge actively by creating ideas to get the concept of knowledge directly, this way of learning will give good effect to the student in understanding knowledge and keep it forever in their mind. Beside that development of authentic assessment in learning process by 2013 curriculum guiding student to mastered the process skill of science. The process skill is so important for student because by this skill student will have the ability in problem solving, like ability to observe, planning, propose hypothesis, interpreting and systematic communication skill.

Theoretically authentic assessment development in learning process by 2013 curriculum focusing to developing project assessment and activities in science material of learning. The implementation is done by scientific learning. All steps of scientific learning are observe, ask, try/test, think, and communicate. 
ICT utilization for authentic assessment model engineering in learning process is already prove can increase the quality of learning process itself. This result should be followed by replacement pattern and expansion type of evaluation model. The used of ICT in a very simple way is as test supporting instrument until types of complex ICT evaluation form which is offer to adopt and adaptation as an alternative solution for contemporer learning evaluation demand.

The strengthen of authentic assessment development in learning process by 2013 curriculum is supporting learning process which is interactive, inspirative, enjoyable, challenging, and motivate student to learn science. The advantage of development authentic assessment in learning by 2013 curriculum is on the searching process and knowledge construction so that teacher only becomes facilitator, mediator, and evaluator in learning process. Teacher do not need to transfer all of their knowledge but challenge student to think and finding own answers from the problem given by teacher or by student itself by class discussing or group discussion based on their daily activities experiences.

It's different with conventional assessment model. The learning process mostly taken by giving all learning material completely and student will only have to answer questions from their book or LKS (student's work book). The practice in only focusing to the material inside the book and not given anything to solve the real problem that will face in daily activities. The student rule during the process of learning is still influence by teacher and its shown when teacher teach the material only from the book. Student doesn't give much time to explore their self to find the knowledge by them self. And because teacher only give the detail learning material from book that make student just understand the concept in theory and can't construct their mind abstractly based on the knowledge they have.

Conventional assessment model in more focusing on teacher centered. Operationally it's started by (1) the beginning activity, teacher give introduction as the beginning steps and tell the material on that period, (2) main activity, teacher explain all the learning material completely, (3) teacher ask student to answer the question from their book of LKS, (4) closing activity, teacher takes evaluation or give some others question that should taken as home work. The learning process in conventional model will going on when there is teacher that given the material or direction to the student to learn from the detail material that they give. Without teacher this conventional model will not happened optimally and conducive appropriate with its purpose. The learning process in conventional model mostly used extracurricular lecture in explain the material without using any other way that more effective and innovative. During its process student is need to listen and have their notes about what teacher said during the learning process. This way will make student become passive, sleepy, and feel bored during the class, and makes the learning activities less effective.

Conventional learning model is only used material from the book and LKS without try to find material from any other relevant sources that supported the learning to be more innovative. Besides that the learning media that used in conventional model is only the blackboard and it's lime. Its way of learning will make student only understand the knowledge in one way/source and it's still in imagination or verbal because the learning sources that used by teacher not reflect that learning should be from many sources.

On the strength of explanation above about the development of authentic assessment in learning process by 2013 curriculum and conventional assessment model can be shown that conceptually and operationally those two assessment model has clear differences. During the learning process that implementing this two assessment model there will be different result.

The development of authentic assessment in this research is assessment development process that strengthen to collect student's data which is done during the learning process and learning outcome which is used as feedback for the progress of student's learning and as matter to taking decision toward student's status (formative and summative)

The result of research from Wiggins (1993) which is showed that authentic assessment is "engaging and worthy problems or questions of importance, in which students must use knowledge to fashion performances effectively and creatively. The tasks are either replicas of or analogous to the kinds of problems faced by adult citizens and consumers or professionals in the field." It can be known by student's activities when they look actively in solving the problems by using their knowledge in effectively and creatively.

Besides that, the result of this research support statements which are revealing by some experts about learning process. According to R. J. Sttigin (1994) reveal that learning model and assessment is cannot be separated because assessment will give description about student's progress and learning process effectiveness. According to L. Fidrani, and S. Pujiastuti (2010) tells that assessment is a part that cannot be separated from learning process because assessment is a process to know student's development and competence documentation. According to Lynn S. Fuchs that quotes by Zainul Asmawi (2001) reveals that performance assessment can improve the process of learning because performance assessment help teacher/lecture to making decision during learning process. According to Buana (2015) tells that assessment is an activity to evaluate an object, like good-bad, effective-ineffective, success-unsuccessful and others that appropriate with the criteria which is set before. According to Sudijono (2011) reveals that assessment id means evaluate something, whereas evaluate means making decision about something based on measurement of good or bad, healthy or sick, clever or bovine and etc. And according to Norman E. Gronlund (1985) tells that evaluation is a systematic process determining the extent to which instructional objectives are achieved by pupils.

Based on the explanation above, theoretically as well as empiric operationally can be known as the student's learning outcome through the used development authentic 
assessment in learning process by 2013 curriculum is higher than the student which is learned through conventional assessment. It's also shown by average descriptive score of student's learning outcome, the student's learning outcome through the used development authentic assessment in learning process by 2013 curriculum is has higher score than the student which is learned through conventional assessment. It can be identification by some finding from researcher that showed the superiority of development authentic assessment learning process by 2013 curriculum as compared to conventional assessment, which is as follow:

First, during the learning process student look enthusiastic because the learning process by development authentic assessment learning process by 2013 curriculum always taking the learning material contextually or related to student's experiences in their daily activities. Besides that, the learning process used many learning media to support student understanding the learning material like pictures, power point, and videos. Learning through pictures and videos will create interesting and enjoyable learning, so students will learning IPA in enthusiastic.

Second, the student during the process of learning be more active because they ask to join the activity actively by practical work and group discussion. During practical work and discussion all students are active and enthusiastic in preparing their equipment's for practical work to answer the question in LKS. This practical work and discussion give the student change to develop their skills and ability to solve the problems that face during the learning process. It's also help student to construct their knowledge by real activities or practical.

Third, development authentic assessment in learning process in 2013 curriculum implementation is so interesting and enjoy full because student is ask to joint through observation in the school or surrounding area. This way of learning will motivate student to learn IPA in deeply by real observation so student will not feel bored and sleepy during their learning process.

Fourth, because of the feedback, student will more motivated in improving their achievement. In the next day they will become more ready to join the learning process.

This result is also supported by data recapitulation of student's respond after the class, it's profitable that student felling new with the learning process that used authentic assessment based on ICT especially with the learning process and the media itself. It's showed by $100 \%$ student's respond. Besides that student fell interesting with the material (learning source) and it's also showed by $100 \%$ or student's respond. Those respond tells that learning process by using authentic assessment based on ICT increasing student's motivation and student's learning enthusiasm. this matter is appropriate with motivation theory that reveal by Nur (2008) which is tells that motivated student will used their highly cognitive process in learning, so they will understand and precipate also remembered the learning material in the best way.
Besides that, in the learning process by authentic assessment based on IT student is asking to structured and proceed in learning process. Student is ask to learn based on the steps that already given. If student can't finish it, they will directly correct to give feedback. This kind of learning will give positive impact to student's learning outcome. Learning through authentic assessment ask student to be more active in learning process, starting by arranging lesson plan, learning implementation, and evaluation. By implementing ICT in learning process, the process of learning will be more meaningful and real, it's means that student ask to get the relation between learning inside the class experience with real life. It's so important because by able to making correlation between the material that get inside the class with real life will make that material have their function in a functional, and also those material will be inside student's mind and difficult to forget it.

The implication by this research finding is IPA learning will give optimal outcome if the learning implementation is using constructivism learning paradigm. Development authentic assessment in learning process by 2013 curriculum has function as feed back to the student to improving their self. Besides that development authentic assessment is one of the constructivism paradigm development based, it can be known by giving the student real activities, so their IPA learning become more meaningful and student can develop their knowledge more active than their early knowledge. The development authentic assessment in learning process by 2013 curriculum not only focusing to student individually, it is also optimizing group working and responsibilities. The development authentic assessment in learning process by 2013 curriculum be considered in order to increasing students learning outcome.

\section{CONCLUSION}

Based on the result and working through above, it can be conclude that development authentic assessment based on ICT in learning process by 2013 curriculum has influential toward student's learning outcome in the fifth grade elementary school cluster V Sukasada sub-district Buleleng regentcy academic year 2013/2014.

It's suggest to all the teachers which is already or will implementing the 2013 curriculum to be more effective in learning process by developing authentic assessment their learning by 2013 curriculum. To support and improve this result of research, it's suggested to do the sort of research in more subjects and sample, also in wider area and different grade of student.

\section{REFERENCES}

[1] A.A.G. Agung, Metodologi Penelitian Pendidikan. Singaraja: Undiksha, 2010.

[2] S. Arikunto, Dasar-Dasar Evaluasi Pendidikan (Edisi Revisi). Jakarta: Bumi Aksara, 2002.

[3] E.B. Johnson, Contextual Teaching and Learning. California: Corwin Press, Inc., 2002. 
[4] A.A.I.N. Marhaeni, Asesmen Pembelajaran Tematik di SD Kelas Awal. Singaraja: Undiksha, 2008.

[5] A.J. Nitko, Educational Assessment of Students, $2^{\text {nd }}$ Ed. Columbus, Ohio : Prentice Hall, 1996.

[6] R.J. Stiggins, Student-Centered Classroom Assessment. New York: Maxwell Macmillan International, 1994.

[7] Sugiyono. Metode Penelitian Pendidikan Pendekatan Kuantitatif, Kualitatif dan R\&D. Bandung: Alfabeta, 2008.

[8] Pusat Kurikulum, Pengembangan Silabus Kurikulum Berbasis Kompetensi. Jakarta: Balitbang Depdiknas, 2002.

[9] Hancock, Beverley and Division of General Practice, An Introduction to Qualitative Research. England: Trent Focus, 2002.

[10] Nazir, Moh. Metode Penelitian. Bogor: Gralia Indonesia, 2005.

[11] Nur, M. Dan Wikandari, P.R. Student Centered Learning and Constructivist Approach in Learning. Surabaya: PSMS Universitas Negeri Surabaya, 2008.

[12] Meleong, Lexy J. Metodologi Penelitian Kualitatif. Bandung: Remaja Rosdakarya, 2009.

[13] Akbar, Sa'dun, dan Hadi Sriwiyana. Pengembangan Kurikulum dan Pembelajaran: Ilmu Pengetahuan Sosial. Yogyakarta: Cipta Media, 2010.

\section{Authors' Profiles}

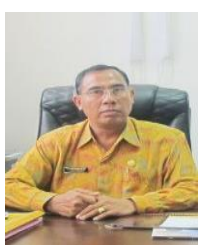

Dr. I Nyoman Jampel, M.Pd. was born in Badung, October $10^{\text {th }} 1959$. He worked as Rector at Ganesha University of Education. $\mathrm{He}$ was received Doctor in Educational Evaluation and Research from Jakarta State University. He also as lecturer of statistics, methodology of educational research and evaluation in various departments, including the Department of Early Childhood Education, Department of Primary Education,
Department of Educational Technology, and the Department of Guidance and Counseling.

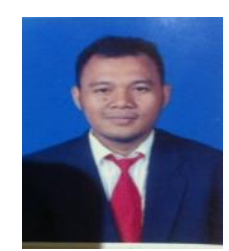

Dr. I Wayan Widiana, M.Pd. was born in Banjar Sari Tunas Tianyar village, Kubu district, Karangasem regency, Bali Province, on July $5^{\text {th }}, 1985$. He was received Doctor in Educational Evaluation and Research from Jakarta State University. He worked as Lecturer of Statistics, Methodology of Educational Research and Evaluation in Department of Primary Teacher Education at Ganesha University of Education.

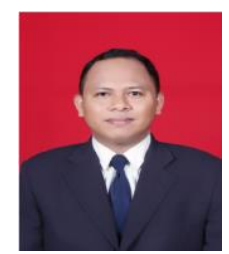

Dr. Dewa Gede Hendra Divayana, M.Kom.was born in Denpasar, July $24^{\text {th }}$ 1984. He was received Doctor in Educational Evaluation and Research from Jakarta State University. He worked as Lecturer of Statistics, Educational Evaluation, Algebra, Database, Expert System, Decision Support System, Object Oriented Programming in Department of Information Technology Education at Ganesha University of Education.

How to cite this paper: I Nyoman Jampel, I Wayan Widiana, Dewa Gede Hendra Divayana,"The Effect of Implementation Authentic Assessment Development Result based on ICT Toward Student's Learning Outcome in Learning Process by 2013 Curriculum", International Journal of Modern Education and Computer Science(IJMECS), Vol.8, No.5, pp.32-38, 2016.DOI: 10.5815/ijmecs.2016.05.04 